IP Periodica Polytechnica

48(1), pp. 45-52, 2017

https://doi.org/10.3311/PPar.10410

Creative Commons Attribution (i)

RESEARCH ARTICLE

\section{The Condition of Immovable Cultural Heritage outside the Urban Context in Vojvodina: the Case Study of the Spitzer Villa in Beočin}

\author{
Viktorija Aladžićc ${ }^{*}$
}

Received 14 December 2016; accepted 01 April 2017

\begin{abstract}
A separate part of the cultural heritage of Vojvodina is represented by around fifty castles, villas and summerhouses located far from the urban environment, mostly constructed in the $18^{\text {th }}$ and $19^{\text {th }}$, as well as at the beginning of the $20^{\text {th }}$ century in the Hungarian part of the Habsburg Monarchy. This paper explores and draws attention to the present condition of the majority of these buildings, and specifically to the case of the Spitzer Villa in Beočin (Belcsény). The Spitzer Villa represents a unique building, designed in the style of historicism, and is also one of the earliest buildings containing Secessionist style decorative elements in Vojvodina It is also a pioneering example of the use of concrete as the main construction material. The research was undertaken in the field, within the competent institutions, as well as through examination of the available literature and scientific papers. Special attention was dedicated to the potentially different treatment of this corpus of architectural heritage, with particular emphasis on the contemporary research in the field.
\end{abstract}

\section{Keywords}

building heritage, Vojvodina, villa, heritage management

\section{Introduction}

Although often neglected in certain environments, cultural heritage is an important element of modern living. It secures cultural continuity, identification and strengthening of individual and collective identity, respect for other cultures and the diversity of cultural expression; all these being particularly important in the context of Vojvodina. Cultural heritage represents the basis of knowledge for the development of a creative society and economy. It is a token and keeper of cultural codes and archetypes, defining the authentic creative output of certain area and may serve as a basis for the development of creative entrepreneurship. In Vojvodina, however, there is an entire series of buildings that belong to the representative examples of the cultural heritage created in $18^{\text {th }}$ and $19^{\text {th }}$, as well as at the beginning of the $20^{\text {th }}$ century, and yet they are completely neglected and largely excluded from modern living. These are castles, villas and summer houses built on the estates of large landowners during the times when Vojvodina belonged to the Habsburg Monarchy, and later Austria-Hungary. One of the partial causes for such condition is their relative physical removal from modern roads and urban environments, but also the prevailing disinterest of the community for their preservation.

\section{The Condition of Castles and Summerhouses in Vojvodina}

According to the data provided by the Provincial Institute for the Protection of Cultural Monuments in Novi Sad, Vojvodina has a recorded total of 53 buildings belonging to the group of castles and summer houses, 35 of which are categorised as cultural monuments (Bakić, 2009). ${ }^{1}$

1 Different sources quote different total numbers of such buildings. Since their typology has not yet been assessed, nor has it been precisely defined which types of buildings have been included in these estimations, only their total number is really available. In her book Dvorci i letnjikovci Vojvodine (Castles and Summerhouses of Vojvodina), (2012) Branka Kulić writes of manors/curia, castles and villas (kurije, dvorci, vile), while some other authors use the terms such as kaštel (from kastély in Hungarian) (Duranci, 2005), all pointing to the approximations and imprecision when it comes to defining and categorising these buildings. 
The most comprehensive research of the castles and summer houses in Vojvodina was undertaken by Branka Kulić, art historian, a long-time employee of the Provincial Institute for the Protection of Cultural Monuments (Kulić, 2015). This research faced many different challenges. The erection of buildings in the Hungarian provinces, in the $19^{\text {th }}$ century, was not subject to administrative legislation, unlike the buildings in urbanised communities (Aladžić, 2014). Consequently, original designs were not kept in the archives and records, while the data on the architects and builders of these castles and summer houses could only be obtained indirectly. Many elements that testified to the way of life and the general paraphernalia of the castles were also lost.

Today, most of the castles and summer houses are in an extremely poor state of repair, with many of them being left to decay and practically in ruins, with no possibility of being restored to their original state. The reasons for such a situation are manifold (Aladžić, 2017). After World War I, when Vojvodina became a part of the Kingdom of Yugoslavia, agrarian reform was carried out in which the properties of many landowners were reduced, and their economic power declined. This resulted in a changing ownership of castles, summer houses and villas. After World War II, nationalisation was implemented to abolish private ownership of these buildings and make them state property. Some of the buildings were even demolished. The majority of the castles and summer houses located outside urban environments were left to the management of the newly established agricultural cooperatives, agrarian conglomerates, and social guardianship authorities. The destiny of the buildings after these changes was certainly not uniform. Some of them belonged to highly developed conglomerates that had the means for their preservation, while others were left to small scale cooperatives unable to finance even regular repairs for these buildings. The buildings located closer to urbanised environments, or in central areas of small settlements were repurposed to have a cultural or educational function. Here, in most cases, the funds were insufficient to provide for the buildings' upkeep, or the works to restore or conserve them (Kulić, 2015.).

After the wars of the 1990s, on the territory of former Yugoslavia, the situation became even worse. In the period of the wars and transition, many of these buildings were entirely abandoned and left to decay. In many of the cases, the ownership had not been changed from national and state to private, and this situation was conducive to their further deterioration. Some of the buildings have been waiting for decades for their privatisation procedures to be finalised and their ownership changed. Unresolved ownership leaves the buildings uninhabited, which often leads to vandalism and damage to the buildings by the local population. In some of the cases, intervention work has been performed on the buildings, usually partial restoration, to protect them from further decay; yet these interventions more often contributed to their devastation and compromised their authenticity, than served the original purpose of their true preservation (Aladžić, 2017).

\section{The Spitzer Villa - Construction and Historical Context}

The construction of the Spitzer Villa was connected to the foundation and development of the Beočin cement factory (Fig. 1). The early utilisation of marlstone for the production of cement in the vicinity of the present day settlement of Beočin, on the slopes of Fruška Gora mountain; coinciding with the construction of the Széchenyi Chain Bridge in Budapest (1839 - 1849) (Brody, 1988). József Csik founded the first factory producing "Roman" cement in the Habsburg Monarchy in 1855. Marlstone was baked in this factory and ground in the primitive floating mills on the Danube River. Five years later, in 1860, Heinrich Ohrenstein from Timisoara leased 20 acres of land from the Beočin Monastery and began producing Roman cement in his newly established "Centrala" factory. After visiting the 1867 World's Fair in Paris and working in an English cement factory, Csik mastered a new technology and began producing substantially superior Portland cement (Gaćeša, 2008). Later, the "Redlich, Ohrenstein, Spitzer" company bought Csik's factory, and it was registered in Budapest in $1900 .^{2}$

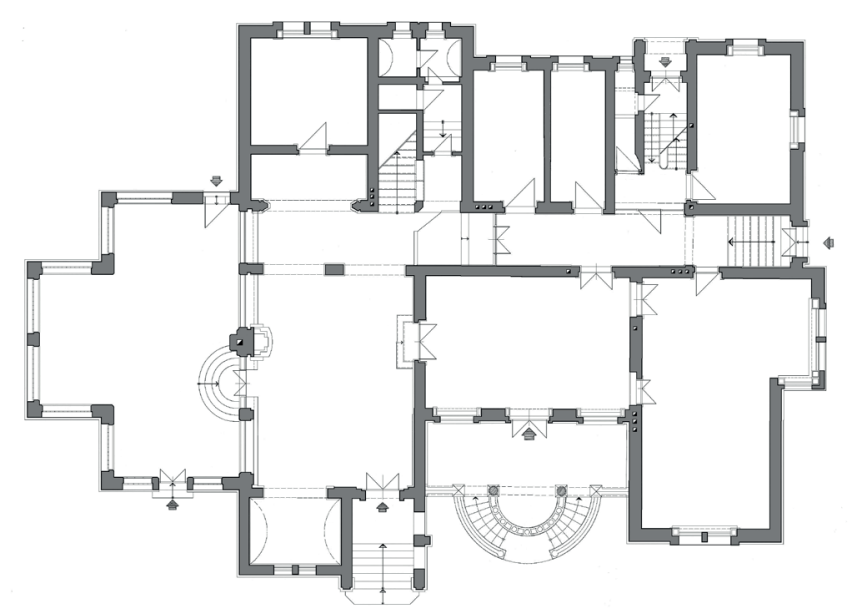

Fig. 1 Spitzer Villa - ground floor plan (Drawing: Viktorija Aladžić 2016)

One of the shareholders of the Beočin located cement factory, Eduard Spitzer, a wealthy landowner of German origin, erected his villa in Beočin in $1898^{3}$ to live there with his family. He was married to Baron Heinrich Ohrenstein's daughter, who worked as a teacher of the cement workers' children in Beočin (Kulić, 2015). To date, the original design of the Spitzer Villa has not been found during the research. Duranci B. (2005), in his book about Vojvodina Secession, writes about the Spitzer Villa and relies on oral evidence when claiming that the architect of the villa was Imre Steindl (1839 - 1902). Branka Kulić (2015) also claims that the villa was designed by Imre Steindl,

2 https://nyr.eleveltar.hu/bflquery/detail.aspx?ID=1006279

3 Today, the villa is situated in a park between Beočin Village and the Municipalty of Beočin (Latitude: 45.203659, Longitude: 19.719902) 
and this position is affirmed by other researchers: Ana Radovanac (2012), Bogdan Janjušević (2014). Conversely, in his doctoral thesis, József Sisa unambiguously insists that the author of the Spitzer Villa was Ignác Alpár (Sisa, 2004), while also stating that 1898 was the year of its construction. According to him, there are two sources for this claim: Magyarország képes albuma (around 1896) and the book by Vilmos Magyar: Alpár Vilmos élete és működése. III. Mercur szolgálatában 18971918. In: Budapesti Építőmesterek Ipartestülete V. évkönyv. Budapest, 1934. The year of the villa's construction is also inscribed on the plaque above the main entrance of the building.

The complex in which the Spitzer Villa was erected comprised a spacious park with a fountain, two pools, a building for servants and the summer pavilion. What disrupted the unity of the complex was the iron structure of the marlstone conveyor, erected above the complex in the immediate vicinity of the villa, and still functional today.

After the departure of the Spitzer family, at the onset of the WWII, the villa accommodated German military headquarters. After the war, the complex was nationalised, and given to the municipal administration of Beočin; its purpose has changed a number of times since. For periods of time, it served as natural spa and resort for the disabled war veterans named "Fruška Gora", a primary school, library, community centre, radio station and finally, an exclusive restaurant "Stari Dvorac (Old Castle)" welcoming international hunt enthusiasts. After the Podunavlje company, which had leased the villa, was privatised, the building became empty and was left to decay (Radovanac, 2012).

\section{Architectural Analysis of the Spitzer Villa}

Spitzer Villa is a freestanding building, with the segmented base, cellar, ground and first floor. The building was designed in the style of historicism with Secessionist decorative details. The main entrance faces south (Fig. 2), and it is connected to a corridor in the building, extending in an east-west direction. On the west side of the corridor, there is a side entrance, while the eastern branch of the corridor leads to an indoor garden, adjacent to the large parlour (Fig. 1). Smaller lounges on the ground floor are oriented northward, while the central lounge opens onto a terrace overlooking the back garden of the villa. The parlour is also connected to this garden, via a separate exit. It is also connected to the first floor via a staircase attached to the corridor.

The central corridor connecting the rooms upstairs also extends from east to west, while its eastern end opens into a gallery, which is roofed with decorative wooden ceiling and overlooks the open space of the ground floor parlour. The Northern wing of the first floor comprises a separate apartment directly connected to a bathroom and a loggia located above the ground floor terrace, also oriented towards the back garden. The Southern side of the corridor leads to two additional bedrooms. The cellar, which is located under the major part of the ground floor, includes the kitchen, store and utility rooms.

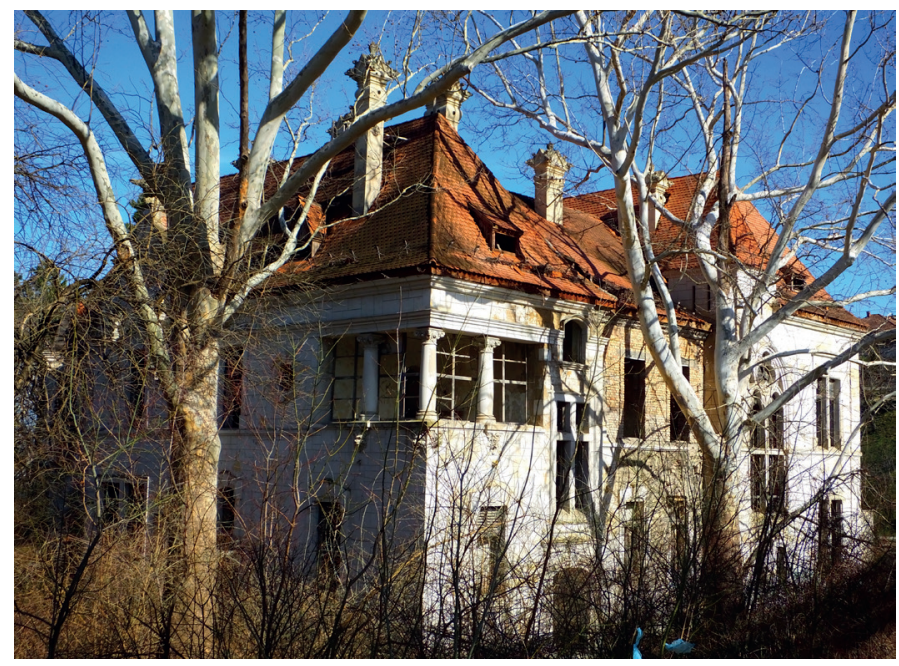

Fig. 2 Spitzer Villa - south façade before roof demolition (Photo: Predrag Komljenović 2016)

The segmented base of the villa, with its four entrances, loggias and terrace, facilitated the concept of eye-catching façades, each different from the others. The façades have rectangular, circular and arched windows, where almost every separate light opening was conceived differently. The most representative is the three-mullioned window in stained glass located on the northern façade and providing light for the parlour (Fig. 3). On the southern façade, there is a two-mullioned window, also in stained glass, lighting the stairwell. The projecting parts of the building are covered by steep roofs, evoking the steepness of Gothic roofs, while the villa has two additional turrets.

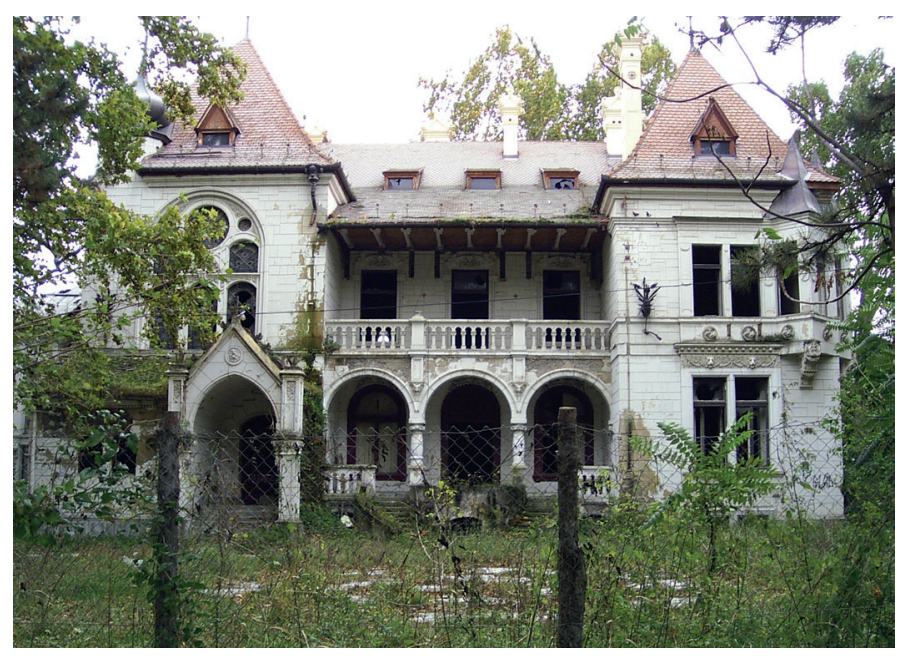

Fig. 3 Spitzer Villa - north façade (Photo: Predrag Komljenović 2004)

The many chimneys have decorative heads, while on top of the triangular tympanum of the western façade, there is a sculpture of the Hungarian mythical Turul bird (Fig. 4). The western façade, besides regular rectangular windows, also includes a circular window and an angular loggia. The opulence of architectural details is completed with many decorative elements made of plaster and wrought iron. All these elements contribute to the daring composition and decoration, with different 
historical styles being boldly combined in an original way, while additional Secessionist style details serve as embellishment. The façade comprises a multitude of sculptures with different symbolic meanings, including the heads of an owl, eagle, dragon, ram, child faces and masks.

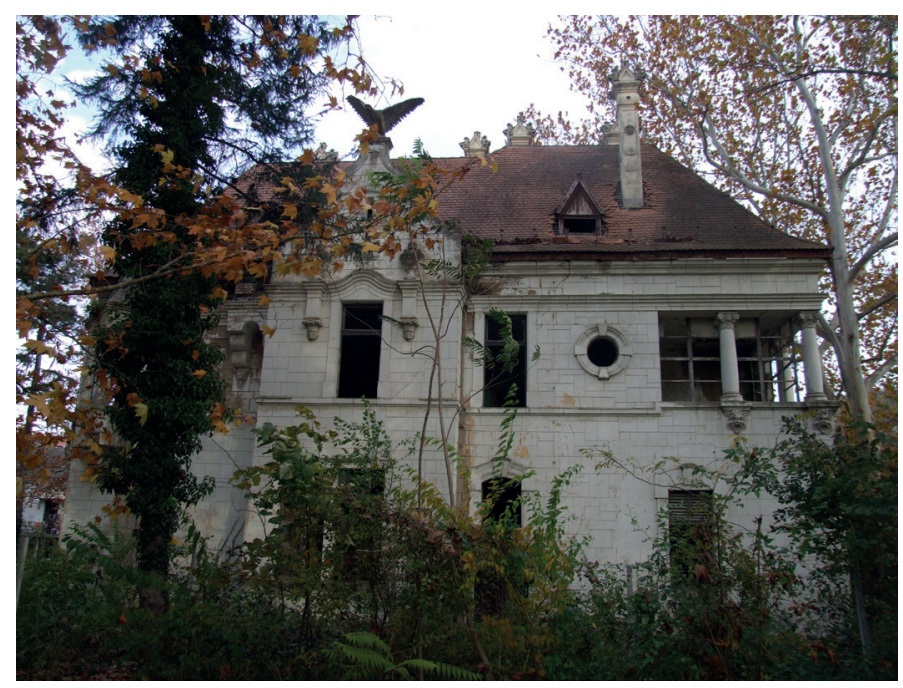

Fig. 4 Spitzer Villa - west façade (Photo: Viktorija Aladšić 2014)

The interior of the building is also skilfully and opulently decorated, especially the parlour area (Fig. 5). Here, the gallery fence contains elements, which are interwoven in a way almost Romanesque; oriental sinuous tympanums above the doors include a multitude of painted details, while the ornaments and stained glass are Secessionist in style. Furthermore, the hall includes a large decorative fireplace, made of Zsolnay ceramics.

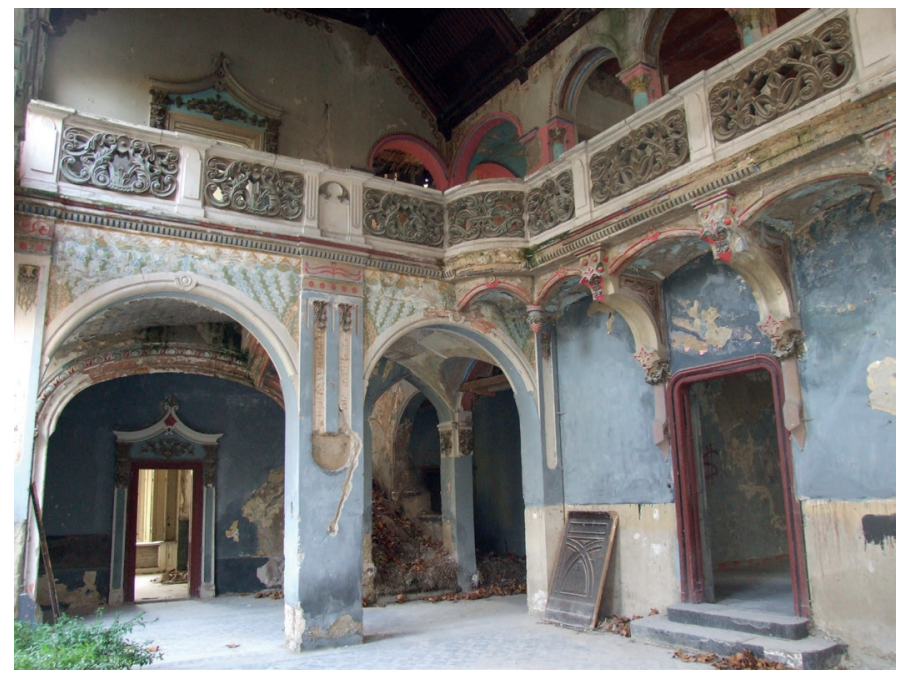

Fig. 5 Spitzer Villa - parlour interior (Photo: Viktorija Aladžić 2014)

The villa represents a valuable architectural work, due to both its decoration and internal spatial organisation, and it is one of the earliest buildings in the Vojvodina area containing Secessionist architectural elements. Additionally, the villa marks a turning point in the application of construction materials. Eduard Spitzer, as the owner of the cement factory, surely deemed the erection of the villa as a good advertisement for his cement production, as he had invested a large amount of his capital into the business. The construction of the villa involved extensive use of concrete, both for walls and ceilings, in combination with steel girders. Cellar and ground floor walls were made of concrete and larger stone pieces, with gravel and slag as aggregates, while the first floor walls intermittently involved the use of concrete made with finer aggregates (Fig 6). The ceilings of the corridor and bathrooms were also made of fine-aggregate concrete. The walls are in places coated with brick. The roof structure is made of wood, just like the ceiling of the parlour.

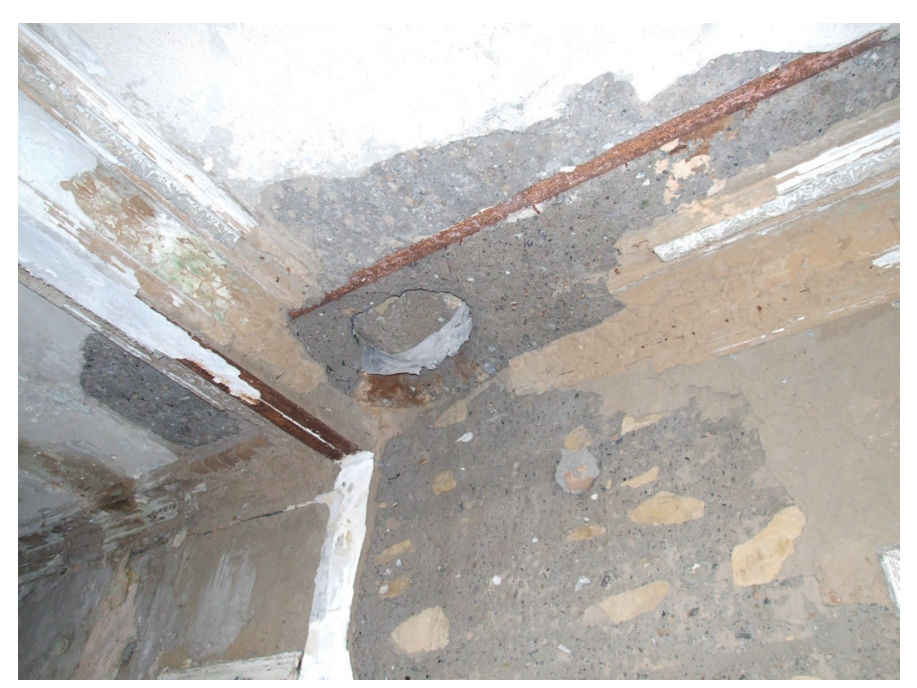

Fig. 6 Spitzer Villa - concrete wall and ceiling on the second floor (Photo: Viktorija Aladžić 2014)

\section{Deterioration of the Villa and its Present Condition}

Judging by the photographs kept in the Provincial Institute for the Protection of Cultural Monuments, at the beginning of the 1990s, the villa was dilapidated, yet all the most sensitive elements were still preserved: stained glass, windows, doors, fireplace, decorative elements. Upon inspection of the villa in 1996, representatives of the Institute sent a letter to the public utility company "Land Development and Road Infrastructure" based in Beočin. They reported on the physical condition of the building and proposed facilitating conservation requirements, in order for the public utility company, as the beneficiary of the building, to be able to begin the works on the building's renovation. ${ }^{4}$ The letter stated that the roofing was completely worn out, with water penetrating the roof thus damaging the wooden structure; parts of the first-floor ceiling had fallen off; the chimneys were in danger of collapsing; horizontal gutter elements had been torn, and some of the vertical rainfall outlets were missing altogether. Consequently, rain had washed away parts of the façade.

4 Case no. 03-199/5 dated 11 October 1996, records of the Provincial Institute for the Protection of Cultural Monuments (hereinafter PIPCM), Novi Sad. 
The procedure of declaring the villa a cultural monument ensued during 1996. ${ }^{5}$ On 18 June 1997, the Serbian Government adopted the decision by which the Spitzer Villa in Beočin was proclaimed a cultural monument, and which also included the measures of technical protection of the building and its surroundings, yet failed to identify the sources of funding for the implementation of such measures. ${ }^{6}$ The villa thus became the responsibility of the Provincial Institute for the Protection of Cultural Monuments in Novi Sad, while simultaneously still being owned by the Municipality of Beočin. This was followed by the recording of the present condition, for the purpose of establishing conservation requirements.

Based on the Decision issued on 10 April 2000 by the Provincial Institute for the Protection of Cultural Monuments, works were performed on reconstruction, recovery and restoration of the roof including replacement of the tiles, reconstruction of the chimneys, replacement of the roof tinwork, repairs of the damaged ceiling and instalment of the missing roof joinery. ${ }^{7}$

During February 2005, a professional team of the Provincial Institute for the Protection of Cultural Monuments established that unknown persons had stolen copper elements from the roof of the villa, thus damaging the roof, upon which, a request for initiation of criminal proceedings against the unknown persons was submitted. ${ }^{8}$

The abandoned villa was used as a set in a number of films: "Black Cat, White Cat" (1996.), "The Brothers Bloom" (2007.), "Mala Ana" (2008.), etc. The presence of film crews additionally contributed to the damage to the building. Deterioration of the overall condition of the villa continued due to weather conditions and vandalism. Gradually, all the interior elements, that could easily be removed were taken. Parts of the fireplace were broken and scattered, the glass panes and stained glass elements were broken, and ceramic tiles from bathrooms were stripped off. Certain walls partly collapsed due to rain and frost, mortar and decorative elements of the façade have cracked and fallen off.

In October 2011, the Provincial Institute issued the decision on the measures for technical protection and undertaking intervention work to restore the Beočin villa. These works once again included inspection and repairs of the roofing, replacement of the damaged parts of the wooden construction, repairs of the gutters, roof dormers, and decorative elements of the roof. ${ }^{9}$

During 2014, the Municipal Council of Beočin sent a letter in which it authorised the Public Utility Company "Land

5 Case no. 01-13/70-96 dated 4 June 1996, records of the PIPCM, Novi Sad.

6 Official Gazette of the Republic of Serbia, No. 26. Belgrade, 1997.

7 Decision no. 03-53/7-2000 dated 10 April 2000, records of the PIPCM, Novi Sad.

8 Case no. 03-56/1-2006 dated 13 February 2006, records of the PIPCM, Novi Sad.

9 Decision no. 03-312/1-2011 dated 14 October 2011, records of the PIPCM, Novi Sad.
Development and Road Infrastructure" from Beočin to undertake measures to prevent trespassing upon the villa and its surroundings, by erecting a protecting fence and a warning sign. These measures, however, failed to prevent unauthorised entries. Around the villa, during the years, vegetation has spread, fully covering the pavement and area around the main gate, and is now threatening to cover parts of the building.

In recent years, efforts have been made to find some sort of solution for the villa. The Municipality of Beočin does not have enough funds at its disposal to finance the restoration and recovery of the building, so it has been attempting to rent it, i.e. to find an investor who would enter into a long-term lease and restore the villa. In the meantime, a few attempts to lease the villa have failed. ${ }^{10}$

In September 2016, the Ministry of Culture and Information of the Republic of Serbia agreed to the removal of the villa's roof structure to prevent it from collapsing. On that occasion, the entire roof was disassembled, and the temporary roof structure was constructed using the material of the existing roofing (Fig. 7). During these works, three of the ten chimneys, with decorative chimney-heads, previously restored, collapsed, and are now lying in the rubble around the villa. One of the heads damaged the metal framework of the winter garden and is currently lying on the floor, beneath the damaged structure. A portion of the material and tiles removed from the roof have been stored in the villa corridor, to be used in future restoration of the original roof. The design for static repairs of the buildings is expected to be made, followed by the designs for reconstruction and conservation. The doors and windows openings were permanently boarded up. However, some of the boards have already been removed by unknown persons and trespassing is again occurring. Rubble is scattered all around, including the remains of the bitumen seals used in the roof restoration of 2000 (Fig. 8). Great piles of rubble from the collapsed roof can also be found on the floor of the upstairs rooms. The rubble also contains parts of the ornaments broken during the removal of the roof.

\section{What is required}

The changes that have taken place in Serbia in the last two and a half decades are quite complex and have influenced all aspects of life. The transition from the socialist government to market economy entails a re-examination of the complex relations with the past, where the question of heritage holds a highly important role. The state still holds the primary role in state-owned heritage protection and management (Ashworth and Tunbridge, 1999), yet, when it comes to the majority of castles and summer houses, this role usually includes only identification and registering of immovable cultural heritage. The interventions of

10 http://www.politika.rs/scc/clanak/158419/Dvorac-izgubljenih-dusa, http://arhiva.24sata.rs/novi-sad/vesti/vest/pogledajte-dvorac-duhova-postajemuzej-foto/155644.phtml 


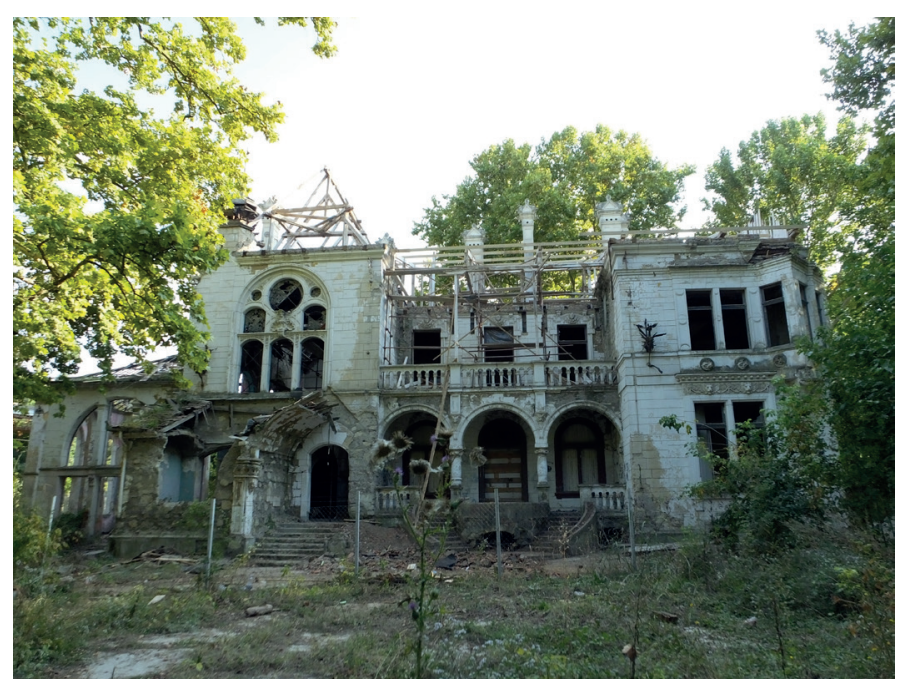

Fig. 7 Spitzer Villa - north façade after removal of the roof (Photo: Predrag Komljenović 01.10. 2016)

physical protection and restoration are as a rule incidental, partial and insufficient. In most of the cases, this heritage is left to decay, due to a variety of the reasons above.

In the wider European context, in the last two decades, much research has been carried out; consequently, there are good practice examples, which could serve as models for research, planning, preservation and management of the heritage on the territory of Vojvodina. Particularly valuable are the research projects from the neighbouring countries, since the Vojvodina heritage shares similar problems with the heritage of the countries in the immediate neighbourhood.

The research by Dávid Kutasi and István Vidovszky emphasises the importance of continuous maintenance and care of buildings, as it requires less financial means than periodic restorations, once the buildings have been neglected for some years (Kutasi and Vidovszky, 2010). The scope of neglect and dilapidation of certain castles, like the Spitzer Villa, which lost their function at the beginning of the 1990s, is such that it becomes questionable whether any work on their restoration and revitalisation would be justified. Both regarding their authenticity and the excessive costs of their conservation and restoration. Continuous care of the buildings would produce much better results in the long run. However, care measures were not taken. Furthermore, there is a question of sustainable function, which in future would secure not only mere maintenance of the buildings but also generate income to justify the resources invested in their restoration. This also opens the question of investment into restoration and revitalisation of these buildings.

Economic justification of investments in the buildings belonging to the corpus of cultural heritage has also been the subject of different research papers and projects. If each environment has certain specificities, and every segment of cultural heritage has its specific traits, it is not possible to merely transplant ready-made solutions from other environments and communities. Nevertheless, the research projects realised in other

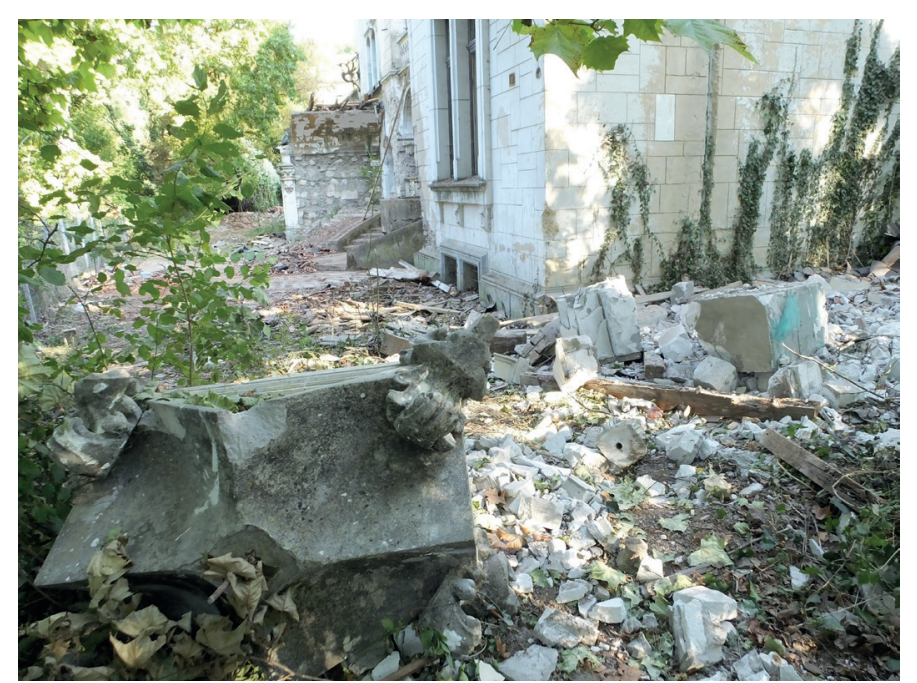

Fig. 8 Rubble around Spitzer Villa after the demolition of the roof (Photo: Predrag Komljenović 01.10. 2016)

environments may serve in defining the guidelines for the, ever so necessary, research projects, pertaining to restoration and revitalisation of castles and summer houses in Vojvodina. One such example is the research on the influence of the economy on cultural heritage realised in Røros (Bowitz and Ibenholt, 2009). This research sums up the possible economic effects of investments into cultural heritage, which certainly need to be analysed in the case of the Spitzer Villa, as well as in cases of all other castles and summer houses.

The example of the Spitzer Villa shows that none of the segments of modern heritage management were implemented in their entirety, while some of them were absent altogether (Fig. 9). The fundamental precondition for attaining good practice in heritage management is the interest of society in maintaining it. This interest must transcend passive concern and become active, where various actions would directly contribute to heritage preservation. Heritage cannot exist outside the policy and decision-making process pertaining to the future development of certain areas. Policies related to heritage creation and management must be made and implemented by policymakers, private companies, or interested individuals (Ashworth and Howard, 1999).

Active operation needs to involve all levels of the social community, beginning with the Ministry whose active participation is necessary for developing strategies and policies for the preservation of castles, as well as in defining potential instruments to obtain sources of funding for the required restoration works, primarily for those buildings still owned by the state. The corpus of cultural heritage that involves castles and summer houses on the territory of Vojvodina should be recognised as general interest on both provincial and republic levels. In this way, the participation of representatives of both governments in making strategies and policies of heritage management, which would contribute to the preservation of the castles and their re-introduction into the contemporary life of their respective communities, could be secured. Institutions of 


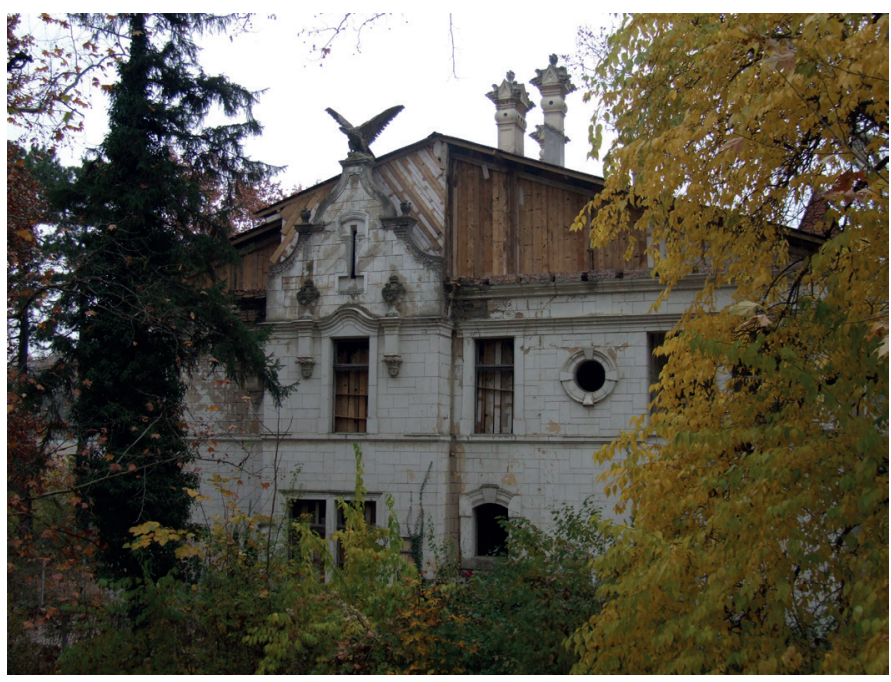

Fig. 9 Spitzer Villa - west façade (Photo: Viktorija Aladžić, November 2016)

urban planning, cultural monument protection and sustainable use need to be governed by those strategies and to actively contribute to their implementation. Vertical coordination between different government levels, as well as the horizontal coordination of different sectors dealing with environmental protection, economic development, education, tourism and infrastructure, need to be practised at all times.

The Spitzer Villa represents an unused resource which, through the implementation of different policy, could become a trigger for local development. To understand the possibility of utilising the villa as a resource, education of the actors who are directly responsible for the building is needed, yet this immediate responsibility is often not precisely defined when it comes to buildings owned by the state. Education and awareness-raising in heritage management represent crucial tasks, which need to be realised by universities, civil society, special institutions and experts involved in the process of urban development, economy, planning and the protection of heritage.

Furthermore, attention needs to be paid to the view that the revitalisation of the castles should facilitate the creation of functional spaces, which could be used once again for the needs of the local communities, either directly, or indirectly. This would also fundamentally contribute to the identity of the local communities, as well as to the regional, national and identity of the wider geographical area. The new function in the case of the Spitzer Villa needs to be connected to the process of branding Beočin, Fruška Gora and Novi Sad, and contribute to the attractiveness and competitiveness of this area. The instruments of location branding were researched by Ashworth (Ashworth, 2009). His research may become quite important and applicable, bearing in mind that Novi Sad has been designated European Cultural Capital for 2021 and that the town of Beočin and the Spitzer Villa may very well fit in into this platform. ${ }^{11}$

11 https:/ec.europa.eu/programmes/creative-europe/news/20161013-ecocnovi-sad-2021 en
Tourism arises as a viable way to achieve sustainability of the Spitzer Villa by utilising the tourist potential of the nearby Fruška Gora and the Danube. Revitalisation of the villa should certainly include protection of the immediate surroundings and landscaping work, the revitalisation of the original park surrounding the villa, as well as its connection to the other protected natural resources on the mountain of Fruška Gora and the Danube River.

\section{Conclusion}

Research work carried on the Spitzer Villa demonstrates its unquestionable value and significance as both local and Central European heritage. However, that the villa belongs to the heritage dating from the era of the Austro-Hungarian Empire makes it potentially inconsistent with the values that might attract the current Serbian political and cultural establishment. On the other hand, the Spitzer Villa shares the destiny of the majority of other castles and summer houses on the territory of Vojvodina. Loss of this part of cultural heritage is not only important at the local level, but also at the level of European Cultural Heritage. To avoid this, quick and comprehensive action is needed. If the action is missing, each day will be a step away from possibilities to preserve the remaining castles, summer houses and villas in Vojvodina.

\section{Acknowledgement}

This paper is based on parts of the research published under the scientific research project entitled "Optimisation of Architectural and Urban Planning and Design in the Context of Sustainable Development in Serbia" no. TR36042, funded by the Ministry of Education and Science of the Republic of Serbia between 2011 and 2016.

\section{References}

Aladžić, V. (2014). Urban planning, regulation and building of towns in $19^{\text {th }}$ century Hungary - Case study Subotica (Szabadka). In: Optimisation of Architectural and Urban Planning and Design in the Context of Sustainable Development in Serbia. (Kurtović, F. N. (ed.)), pp. 535 - 562. Department of Architecture and Urban Planning, Faculty of Technical Sciences, Novi Sad.

Aladžić, V. (2017). Difficulties in the Process of Restoration of Cultural Monuments on the Examples in Subotica. In: Conference Proceedings $5^{\text {th }}$ International Conference Contemporary Achievements in Civil Engineering 2017. (Miličić, I. M., Landović, A. (eds.)), pp. 853-860. Faculty of Civil Engineering Subotica, University of Novi Sad, Subotica.

Ashworth, G. (2009). The instruments of place branding: How it is done? European Spatial Research and Policy. 16(1), pp. 9-22.

https://doi.org/10.2478/v10105-009-0001-9

Ashworth, G., Howard, P. (1999). European Heritage Planning and Management, Intellect Books, Exeter, Portlandor.

Ashworth, G., Tunbridge, J. (1999). Old cities, new pasts: Heritage planning in selected cities of Central Europe. GeoJournal. 49(1), pp. 105-116. https://doi.org/10.1023/A:1007010205856 
Bakić, S. (2008). Pregledfondagraditeljskognasleđa, stanjeobjekata, vlasničkiodnosi, primerineadekvatnihiadekvatnihnamena. In: Dvorciiletnjikovci Vojvodine. (Višerov, J. R. (ed.)), pp. 7-38. Nacionalna asocijacija za ekoturizam „Ekoturizam Srbija“, Sremska Mitrovica. (in Serbian)

Bowitz, E., Ibenholt, K. (2009). Economic impacts of cultural heritage - Research and Perspectives. Journal of Cultural Heritage. 10(1), pp. 1-8. https://doi.org/10.1016/j.culher.2008.09.002

Brody, J. (1988). The Széchenyi Chain Bridge at Budapest. Technology and Culture. 29(1), pp. 104-117. https://doi.org/10.2307/3105230

Duranci, B. (2005). Arhitektura secesije uVojvodini, pp. 39-42. Grafoprodukt, Subotica. (in Serbian)

Gaćeša, L.N. (2008). Istorija fabrike cementa u Beočinu. pp. 17-36. MaticaSrpska, Novi Sad. (in Serbian)

Gerle, J., Kovács, A., Makovecz, I. (1990). A századforduló magyar épitészete. Szépirodalmi Könyvkiadó, Budapest. (in Hungarian)

Janjušević, B. M. (2014). Nastanak $i$ razvoj stambenih palata $i$ vila u Vojvodini oblikovanih u stilu secesije krajem XIX i početkom XX veka. pp. 96-100. Fondacija Akademika Bogumila Hrabakaza publikovanje doktorskih disertacija, Vojvođanska akademija nauka i umetnosti, Novi Sad. (in Serbian)
Kulić, B. (2015). Castles and Summer Houses in Vojvodina, The Provincial Institute for the Protection of Cultural Monuments, Petrovaradin, Platoneum, Novi Sad.

Kutasi, D., Vidovszky, I. (2010). The cost effectiveness of continuous maintenance for monuments and historic buildings. Periodica Polytechnica Architecture. 41(2), pp. 57-61. https://doi.org/10.3311/pp.ar.2010-2.03

Magyarország képes albuma (around 1896.) pp. 33. (in Hungarian)

Radovanac, A. (2012). Baština u krizi - Dvorac Špicer u Beočinu, Sintezis časopis za humanističke nauke $i$ društvenu stvarnos. 1, pp. 63-84. (in Serbian)

Sisa, J. (2004). Kastélyépitészet és kastélykultúra Magyarországon a historizmus korában. Thesis, Hungarian Academy of Sciences. Budapest. (in Hungarian)

Magyar, V. (1934). Alpár Vilmos élete és működése. III. Mercur szolgálatában 1897-1918. In: Budapesti Építőmesterek Ipartestülete V. évkönyve. Budapest. (in Hungarian) 